be successfully attacked by the knife as long as the surrounding parts and the adjoining glands have not become contaminated ; for experience too well demonstrates that there is in this disease a power of generally inducing in the surrounding parts a participation in its morbid influence, and thus gradually extending its formidable ravages.

With regard to the other forms of malignant disease, to which the eye, like other organs, is subject, viz., fungus hæmatodes or encephaloid cancer and melanosis, there is ample scope for making remarks, particularly with regard to the former, as it generally occurs in the earlier periods of life, but I have already perhaps trespassed too long on the time and patience of the society to permit any further extension of this paper on the present occasion.

Before concluding, I should wish to remark that the Manchester Eye Hospital was established in the centre of this populous district about the early part of the year 1815, Mr. Wilson being then appointed surgeon, and the late Dr. Hull physician, to the institution. Mr. Barton was soon afterwards appointed a second surgeon, and a year or two afterwards I was appointed a third surgeon. On the retirement of Mr. Wilson from the office about twelve or fourteen years since, two assistant-surgeons were appointed, Messrs. Hunt and Gordon. After the death of the last gentlemen, Mr. Walker succeeded lim, and Dr. Robinson succeeded Dr. Hull. Our patients annually are about 1,500 to near 2,000 in number.

\section{LIGATURE OF THE FEMORAL ARTERY.}

TO THE EDITORS OF THE PROVINCIAL MEDICAL JOURNAI.

Gentlemen,-I was much interested in the perusal of Mr. Jesse's excellent observations on Hæmorrhage after Amputation, in a late number of your valuable publication. The two following cases, which have recently occurred in this institution, fully corroborate his views, viz., that in hæmorrhage from the thigh, when it is found necessary to secure the femoral artery, the ligature should be applied above the origin of the profunda. If that had been done in the first case, there is but little doubt that it would have prevented the necessity of resorting to a second amputation.

\section{Derbyshire General Infirmary,}

I remain, Gentlemen, Your humble servant, R. Dix, House Surgeon. Feb. 22, 1844.

CASE I.-John Noon, aged twenty-two, by trade a joiner, was admitted into the hospital April 24, 1843, with strumous disease of the left knee. As the malady continued to increase, and his health began to suffer, it was deemed advisable to remove the leg above the knee, which operation was performed, by means of a double flap, a fortnight after his admission. He went on very well until May 15, the ninth day after the operation, when hæmorrhage from the stump took place, which was restrained for a time by pressure, and the constant application of cold ; but it occurred again at intervals on the following day; and at one o'clock, a.m., on the 17 th, to such an alarming extent that life was almost lost. Under these circumstances, after he had rallied, it was judged best to tie the femoral artery; this was effected a little below the profunda. Four days afterwards the bleeding again returned profusely, and it was necessary to amputate the limb two inches above the first site of operation. From this period he went on well, and was discharged cured July 17.

CASE II.-John Whitney, a shoemaker, aged seventeen, was admitted November 27, 1843, having disease of the left knee-joint of five years' duration. As he came into the hospital for the purpose of having his leg amputated, the operation was performed ten days after his admission. The stump had nearly healed, and the last ligature came away on the 30th of December; this was followed by hæmorrhage to a considerable extent. After trying the usual means to suppress the bleeding without effect, the femoral artery was tied in the groin above the profunda. From this time he continued progressing towards recovery, and left the infirmary on the 16th instant quite well.

\section{OBSERVATIONS}

ON THE

TREES AND SHRUBS PROPER FOR OUR PROPOSED NATIONAL CEMETERIES.

By Robert Dickson, M.D.

Conservative Power of Vegetation illustratedExceptions in Coniferous and some other TreesApplication.

\section{TO THE EDITORS OF THE PROVINCIAL MEDICAL} JOURNAL.

Gentubmen,-The perusal of an article, which appeared a few weeks since in your valuable Journal, on intra-mural sepulture, suggested to me the following reflections; and should you deem them worthy of a place in your columns, you will oblige me by inserting them.

I remain, Gentlemen, Your obedient servant, Robert Dickson, M.D.

\section{5, Curzon-street, Mayfair,} Feb. 26, 1844.

In the Observations on Mr. Chadwick's Report on Interments in Towns (Provincial Medical Journal, January 6,1844 ), it is proposed, as a remedy for the manifold evils of this custom, that national cemeteries should be provided at proper distances from the metropolis and other large towns. As a very important part of the economy of such cemeteries, it is recommended to keep the ground covered with a thick turf, and planted with shrubs and trees; it being added, "the purifying effects of regetation on the air are well known." The general truth of this statement is unquestionable, but in its practical application it needs some qualification, since, while certain plants exert a purifying influence over the atmosphere, increasing the proportion of oxygen, others, by diminishing its amount, exercise a hurtful power. As it is chiefly plants of the latter kind which are selected for the ornaments of the resting-places of the dead, I propose to offer a few hints to assist in guiding the 
choice of those who may be appointed to construct and superintend those national cemeteries.

That the simplest states of living vegetable forms contribute to augment the oxygen of the water in which they are developed, is proved by the experiments of many chemists, from the green matter of Priestley, which has been aptly termed " a provisional creation waiting to be organised," up to the most gigantic flags or sea-weeds which "the dark unfathomed caves of ocean bear." The presence of a small moss or conferva in a vase, in which fishes are kept, so markedly aids in maintaining the supply of oxygen requisite for their respiration, that it is not necessary to change the water so frequently as when no such plant is present. On a larger scale the same fact is proved, since it is "notorious that fishes are never so healthy in reservoirs destitute of aquatic plants as in ponds and streams in which these abound" (Carpenter's Comparative Physiology, second edition, p. 338). Were it not for the vegetation, vast in point of number, and huge in point of size or length (the macrocystis pyrifera being occasionally from 500 to 1,500 feet long), and rapid in growth, beyond any parallel in terrestrial plants, which the bed of the ocean maintains, oxygen would be wanting not only for the fishes and molluscs-not to mention the millions upon millions of animalcules which "live, move, and have their being" therein-but also for various chemical actions, carried on at depths to which the oxygen of the air never penetrates, however it may minister to those effected near the surface.

It is, therefore, manifestly a serious error to rake out the regetation from fish-ponds, where, while living, it is directly beneficial to the fish, and spread it out on the banks, when, by converting it into dead and decomposing matter, it becomes directly injurious to man.

The prejudice on this head, entertained against the lemnas or duck-meats, requires to be dissipated, since, far from being noxious, they are truly beneficent plants. Floating as they do in the water, and not furnished with a root imbedded in the bottom of the ponds or ditches, which would prevent them following the rise and fall of the water, but ever readily accommodating themselves to its varying amount, and possessing a peculiar mode of increase and growth, they form a veil over the entire surface, and speedily decompose the gases as they rise, disarming them of their virulence, and liberating the oxygen for the use of animals.

Certain peculiarities in the construction of aquatic plants would lead us to infer that they were designed for this among other offices. Very generally the submerged leaves are frequently divided and feathered, so as greatly to increase the extent of surface, as well as the number of points which attract the gases as they slowly ascend through the water. Still more beneficial is the arrangement prevalent in all submerged parts, of being destitute of cuticle, so that the gases are instantly brought into contact with those cells of the plante whioh poseess the power of decom. posing them, which the cells of the cuticle, being filled only with air, do not.

In tropical climates, where, owing to the greater intensity of the physical agents which accomplish decomposition, sources of disease are more frequent and rapid in their effects, the conservative properties of living active vegetation are clearly demonstrated. The insalubrity of the town of Batavia is well known, yet that side of it next the marshes is less unhealthy than the other next the sea. This immunity is chiefly owing to the action of one very singularly constructed plant, the pistia stratiotes, which abounds in these marshes, placed there apparently expressly for the purpose of diminishing their unhealthiness. "We were surrounded on all sides by marshes, which render this situation (Fort Anké, in Batavia) very unhealthy; it is, however, much less so than that of the town, where, at low water, the black mud collected in a great number of canals is exposed to the heat of the sun, and exhales the most pestilential effluvia. The marshes of Anké, on the contrary, were covered with a variety of plants, so close to each other that they presented the appearance of fine meadows in full vegetation. A great number of different kinds of grasses, rushes, nelumbo, \&c., grew forth from the bottom of the stagnant water, and the interstices between these plants were covered with large quantities of the pistia stratiotes, which, floating on the surface of the water by means of the small bladders with which its leaves are provided at their bases, absorb a great variety of the noxious vapors as fast as they are exhaled from the mud, and change them with the aid of the solar rays, as we know, into respirable air. This transmutation is effected by the pistia more than by any other plant; for it is known by experiment to be so powerful a preventive of the decomposition of stagnant water, that if fishes be put into a small quantity of water, in which they would otherwise perish in the course of a few days, they may be preserved a long time by covering its surface with these singular plants, every one of which occupies a space of about nine square inches." (Labillardiere's Travels, p. 473.)

The effects, on a large scale, of an active vegetation in counteracting a tendency to endemic diseases, and of the absence of it in promoting the outbreak of some of the most formidable of these, is well stated in Russeger's Travels in Egypt, the extraordinary fertility of which he elucidates by tables. "Fertile, however, as is the soil yearly deposited by the Nile on its banks, so long as the soil is carefully cultivated and watered by the hand of man, equally rapid is its conversion into sand and desolation, when man ceases to bestow upon it his care. The mud of the Nile is full of salts, particularly saltpetre, dries up rapidly, and then becomes a light dust, which is soon carried away with the wind. Let man tend it carefully, and there is no soil in the world of greater productiveness; let him neglect it, and, in a little time, this fertile soil becomes incapable of sustaining vegetable life."

The rapidity of the growth of plants useful to man, after the inundation, may be seen by reference to works more accessible than Russeger's, such as Sir G. Wilkinson's "Topography of Thebes." It is left for man to decide whether the overflow of this " abounding river" shall prove a blessing or a curse. The saline principles washed down by it can im. mediately be moulded into forms of beauty and usefulness by the plastic power residing in plants, if their seeds be placed by him in the bosom of the 
earth; but if he fail in discharging the duties assigned to him, these same elements rise up against him, and by inducing fatal disease, remove him as an useless cumberer of the ground.

The relation of man to the earth, and of the earth to man, is mutual, or, as Koreff, in his work $D e$ Regionibus Italia aere, pernicioso contaminatis Observationes, expresses it, "Not only does man need the earth in order to live and be active, but the earth also stands in need of man."

That trees which can be proved to diminish, to lessen, instead of increase, the amount of oxygen, are no fit portion of the vegetation of cemeteries, must be obvious; yet these are those most likely to find a place there, being held to be, almost by prescriptive right, the appropriate occupants of the spots set apart for the dead-" dark trees, funereal, cypress, yew and shadowy pine, and spicy cedar." Which give to our burial-grounds an aspect scarcely less gloomy and repulsive than those in the neighbourhood of Constantinople, so graphically described in "Anastatius."

Evergreens generally are allowable, but all those which contain volatile oils, or volatile constituents in general, which change into resin by the absorption of oxygen (see Liebig's Organic Chemistry applied to Agriculture, first edition, p. 28), are very unfit. If we exclude the coniferous plants above enumerated, we shall still have enough of perennial leaved plants left to maintain an appearance of freshness and life throughout winter, the cherry-laurel (cerasus laurocerasus), the Portugal laurel (cerasus lusitanica), holly, ilex aquifolium, and, above all, the arbutus unedo, and arbutus andrachne, from being clothed during the winter with "blossoms and fruit at once." Where walls surround the cemetery, the mespilus pyracantha, and other shrubs, might be advantageously trained against them. Among deciduous plants it would be necessary to exclude the poplars, especially the populus balsamifera. Along the sides of large cemeteries the ash tree might be planted, as the leaves in this country are rarely eaten by insects, and the roots creeping along the surface would not dip down into the graves as elms would do. The ornus europœa, or flowering ash, would be a suitable tree, more cheerful than the weeping ash.

One of the most appropriate would be the common lilac (syringa vulgaris), the leaves of which have been ascertained by Dr. Daubeny to raise the proportion of oxygen, in a jar filled with common air to 29 or 30 per cent., and by introducing several plants into the same jar in pretty quick succession, even raising the proportion from 21 (the ordinary amount) to 39 per cent., thus almost doubling it. "How great, then," says Dr. Daubeny, "must be the effect of an entire tree in the open air under favorable circumstances!" It is less, however, the object of these remarks to show what plants should, as to indicate what should not, be admitted into our proposed cemeteries.

The cypress, yew, cedar, and arbor vitæ are those I am anxious to exclude. One result of their banishment would be, that a more cheerful aspect would appertain to the spots where the remains of our departed friends repose. They would then invite to frequent visits on the part of the survivors; constituting fit retreats, where "the soul might plume and balance her wings by holy meditation, before she should take her own flight to heaven." All these trees belong to one class, termed non-reproductive, because, when cut down, no shoots spring from the roots. This was one reason why the ancients selected the cypress to plant by the grave, which to them was the end of existence. Viewed in this light, it has been well observed, " the cypress is no meet emblem of the Christian's grave." Let us not, then, lose the present opportunity of casting aside the selected emblems of the heathens, and of those who sit in darkness little less profound, but substitute others, more in accordance with that religion which, having "brought life and immortality to light," forbids us, when we commit "earth to earth, ashes to ashes, dust to dust," to sorrow "even as others which have no hope."

In conclusion, I am not without trust that this sug. gestion will meet with attention, since science and religion alike combine in demanding the change.

\section{ON THE MISCHIEFS}

RESULTING FROM

\section{THE RANDOM ADMINISTRATION OF LARGE} DOSES OF CALOMEL.

By Robert Druitt, Esq., Surgeon, London.

\section{TO THE EDITORS OF. THE PROVINCIAL MEDICAL} JOURNAL.

Gentramen,-I send you the following case for insertion in your valuable Journal, in the hope that it may serve as a caution to your readers against following implicitly a practice which is recommended by very high authorities, but which, as the sequel will show, may occasionally be followed by very serious mischief.

The practice to which I allude is the administration of very large doses of calomel, in order to act as a purgative in puerperal convulsions, or other cases of sudden and dangerous congestive affections. This practice is recommended, however, in puerperal convulsions by a majority of the most popular midwifery authors of the present day.

Dr. Rigby, in his treatise on Midwifery in the Library of Practical Medicine, says, when speaking of the treatment of puerperal convulsions, " eight or ten grains of calomel with fifteen or twenty of jalap, should be mixed into a paste with a little thin gruel, and laid upon the back of the tongue," \&c. \&c.

Dr. F. Ramsbotham, in his "Principles and Practice of Midwifery," says that " ten or twelve grains of calomel may be mixed with a little sugar, and put upon the tongue," \&c.

Dr. Fleetwood Churchill, in his "Theory and Practice of Midwifery," recommends a strong cathartic of calomel and jalap to be administered.

Dr. Merriman says, in his " Synopsis of Difficult Parturition," "If the patient be able to swallow, a pill containing from five to ten grains of calomel may be got down; or the calomel mixed with moist sugar may be put into the mouth," \&c. \&c.

The very learned Dr. Copland, in the "Dictionary of Practical Medicine," Art. Convulsions says, "the exhibition of ten grains of calomel, and from five to ten grains of camphor, with or without an equal 